\title{
Implementation of Quality Infusion Program Services at Bombana Regency General Hospital in 2011
}

\author{
Megawati (Correspondence Author) \\ Akademi Keperawatan Lapatau, Bone, Indonesia \\ Yusriadi Yusriadi \\ Sekolah Tinggi Ilmu Hukum Pengayoman, Makassar, Indonesia
}

Received: Jul. 23, 2019 Accepted: Aug. 15, 2019 Online published: Aug. 28, 2019

doi:10.5296/jpag.v9i3.15129 URL: https://doi.org/10.5296/jpag.v9i3.15129

\begin{abstract}
Nurses as health service at the hospital, they have to be always on ready in 24 hours for performing routine daily activities, and a various emergency, such as critical health condition of patients. The purpose of the research is for knowing the description of service quality of infusion installation program at general Hospital of Bombana Regency in 2011. Characteristic of research is descriptive analysis using statistical descriptive. The population of the research is all nurses on duty at General Hospital of Bomabana Regency in amount 55 nurses. Samples of research are in the amount of 30 respondents from 55 nurses. Instruments which used in this research are questionnaires. Result of research showed that description of infusion installation implementation in preparation phase; 10 nurses (33.33 percent) performed in the good category, 20 nurses (66.67 percent) performed in lack category. While description of infusion installation in implementation phase, 13 nurses (43.33 percent) performed in good category, 17 nurses (56.67 percent) performed in lack category. Suggestion, expected to hospital institution to consider decisions relating to training and education for nurses who still have education at the lower level, in order could increase their knowledge.
\end{abstract}

Keywords: policy, quality service, infusion program, Indonesia

\section{Introduction}

Reform brought changes in various fields of human life, especially in public services (Yusriadi, 2018d). Factors that take into account can improve the ability of nurses in infusion is the characteristics of nurses, which include age, gender, and level of education (Adriani, 2004). Health Services It is an effort that is carried out alone / jointly in an organization to 
maintain and improve health, prevent and cure diseases and restore personal, family, group, or community health. In the 1945 Constitution Article 28 and Article 34 states that the state guarantees that every citizen has a prosperous life, a place to live, health and health services in Indonesia, but dichotomy often occurs in efforts to provide health services, excellent health services only offered to those who are capable while the poor not treated fair and proportionate.

Bombana Regency General Hospital with type D, felt the same problem with other hospitals, namely tight competition. Competition is related to aspects of examination technology, and compatibility in health services (Alamsyah, 2011). Based on patient visit data in Bombana District Hospital every day ranges from 40-50 patients. About 10-20 patients need an intravenous procedure. The report of Bombana District Hospital in 2010 recorded 165 patients had infused with 13 people (7.9 percent) experiencing inflammation around the needle puncture infusion, and pain. Health care is the right of every person guaranteed in the 1945 Constitution to make efforts to improve the health status of individuals, as well as groups or society as a whole.

Based on the preliminary study conducted by the author, the implementation of the infusion carried out by nurses at the Bombana Regional General Hospital starting from the preparation stage to the implementation stage mostly did not carry out the established infusion procedure. This phenomenon shows that nurses' ability in infusion is still lacking. Based on the results of the observations above, the authors will research "Implementation of quality infusion program services at Bombana Regency General Hospital in 2011".

\section{Method}

The research was carried out in the working area of the Bombana District General Hospital in Southeast Sulawesi Province. This type of research is descriptive, to describe the quality of service for infusion programs in hospitals. The population in the study were 55 people at Bombana District General Hospital. The sample study is nurses who care for patients with a purposive sampling selection that is choosing samples among the population according to what the researchers want with a sample size of 30 people. Data collections do with primary data and secondary data, primary data collected using interviews using the observation format designed by researchers. Secondary data in the study were collected by looking at documents (health profile of Bombana District General Hospital). The process of data analysis begins with processing several data that has accumulated. Descriptive analysis is used to describe the results of research presented in the form of a percentage table of respondents' answers to each question for each research variable.

\section{Results and Discussion}

One of the entry points that need intervention to improve public service delivery in Indonesia is changing the institutional framework (Yusriadi, 2018a). The importance of health services for every resident, making ita hospital has an essential role in responding to people's needs for health services. Based on the results of research conducted at the Bombana District General Hospital in 2011 showed that of the 30 respondents, the respondents who carried out 
the infusion at the preparation stage that carried out well were ten people (33.33 percent). Because nurses have enough knowledge about preparation before infusion during college so that they can make proper preparation of tools, this also supported by the education level of respondents who have an average Diploma 3 and also to undergraduate nursing. By the opinion that the higher the level of education of a person. The more natural the individual receives information so that more knowledge is also possessed (Efendi, 2009).

Complete health service activities are regulated in Article 52 paragraph (2) of the Health Law as referred to in paragraph (1), namely:

1. Health improvement services, activities, and a series of health service activities that prioritize health promotion activities.

2. Preventive health services, a prevention activity against a health/disease problem.

3. Curative health services, activity or a series of therapeutic events aimed at healing diseases, reducing suffering due to illness, controlling disease, controlling disability so that the quality of patients can maintain as optimal as possible.

4. Rehabilitative health services, activities or a series of events to return former sufferers to the community so that they can function as members of the population that are useful for themselves and the community, to the maximum extent possible according to their abilities.

Based on the above description of health services held in public health centers, clinics, and hospitals regulated in general in the Health Law, in Article 54 paragraph (1) of the Health Law it states that the implementation of health services is carried out responsibly, safely, quality, and even and non-discriminatory. In this case, each person or patient can obtain health service activities in a professional, safe, quality, anti-discrimination, and effective manner and prioritize the safety of the patient's life compared to other interests.

From 30 respondents, it can be seen the implementation of infusion at the preparation stage, 20 respondents (66.66 percent) did poorly. Due in part to nurses telling researchers that the injection is an action that they have often done, they also feel that in terms of preparation it does not need to be too complete because the most important thing for them is a fast infusion installed. Good governance enables the government bureaucracy to perform quality and efficient public services (Yusriadi, 2018b).

In this case, the action of infusion is normal, but nurses must still follow the ethical principles of nursing practice, namely nurses must continue to work according to the standards of nursing care in general and carry out infusion according to the rules of injection in particular. The role of the Hospital as a curative service provider, rehabilitative, and preventive, occupies an essential position in the health care system. Because of the importance of the role of hospitals in the health care system, various efforts to improve the quality of hospital services are a priority in the development of the health sector (Goetsch, 2008). A service is said to be good or bad, depending on the level of satisfaction of service users based on the quality of the service itself (Notoadmojo, 2005). 


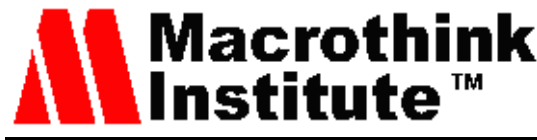

The results of the study at the implementation stage showed that the respondents who carried out well or following the procedure were 13 people (43.33 percent), because nurses already have sufficient knowledge about the process for infusion according to the rules. And of the 30 respondents who carried out poorly or not according to the procedure were 17 people $(56.67$ percent). Because they consider the infusion often done, the most important thing is fast injection installed. One of the processes in developing the capacity of the apparatus is education and training activities (Yusriadi, Sahid, Amirullah, Azis, \& Rachman, 2019).

The hospital is a health service institution that organizes individual health services in a comprehensive manner, which provides outpatient services, inpatient care, and emergency services. Hospital is one of the facilities or place to hold health services. Health care is every activity to maintain and improve health and has the aim of increasing degrees optimal health for the community. Health services organized with a maintenance approach, health improvement, preventive disease (preventive), disease healing (curative) and health recovery (rehabilitative), which is carried out in a comprehensive, integrated and sustainable manner.

\section{Conclusion}

We conclude that the description of the implementation of infusion at the preparation stage both at the Bombana Regional General Hospital in 2011 was 10 people (33.33 percent), and the application of injection at the preparation stage was less than 20 people (66.67 percent) while the description of the implementation of infusion at the implementation stage in the Bombana General Hospital in 2011 there were 13 people (43.33 percent). And the application of immersion at the preparation stage was less than 17 people (56.67 percent). From the results of research and discussion, the authors provide advice for nurses; nurses should in carrying out infusion activities pay attention to the preparation of equipment that will use correctly and in its implementation must refer to the standard application of infusion to prevent infection. Governments around the world build their institutions to achieve the stated goals and objectives (Yusriadi, 2018c).

\section{Reference}

Adriani. (2004). Kepuasan Pasien Terhadap Pelayanan Kesehatan Di Rumah Sakit.

Alamsyah, D. (2011). Manajemen Pelayanan Kesehatan. Yogyakarta: Nuha Medika.

Efendi. (2009). Manajemen Pusat Kesehatan Masyarakat. Jakarta: Salemba Medika.

Goetsch. (2008). Kualitas Pelayanan Kesehatan. Yogyakarta: Ganbika.

Notoadmojo, S. (2005). Ilmu Pelayanan Kesehatan Masyarakat. Jakarta: Salemba Medika.

Yusriadi. (2018a). Bureaucratic Reform Barriers: A Case Study on the One Stop-Integrated Service Office in Bone Regency. Jurnal Kebijakan Dan Administrasi Publik, 22(2), 146-154. Retrieved from https://jurnal.ugm.ac.id/jkap/article/view/34536

Yusriadi. (2018b). Bureaucratic Reform to the improvement of public services Challenges for Indonesia. Publikauma: Jurnal Administrasi Publik Universitas Medan Area, 6. https://doi.org/10.31289/publika.v6i1.1494 
Yusriadi. (2018c). Reformasi Birokrasi Indonesia: Peluang dan Hambatan. Jurnal Administrasi Publik (Public Administration Journal), 8(2), 178-185. https://doi.org/10.31289/jap.v8i2.1824

Yusriadi. (2018d). Tantangan Reformasi Birokrasi Berbasis E-Procurement di Indonesia. Publikauma: Jurnal Administrasi Publik Universitas Medan Area, 6(2). Retrieved from https://ojs.uma.ac.id/index.php/publikauma/article/view/1635

Yusriadi, S. A., Amirullah, I., Azis, A., \& Rachman, A. A. (2019). Bureaucratic Reform to the Human Resouces: A Case Study on the One-Stop Integrated Service. The Journal of Social Sciences Research. https://doi.org/10.32861/jssr.51.61.66

\section{Copyright Disclaimer}

Copyright for this article is retained by the author(s), with first publication rights granted to the journal.

This is an open-access article distributed under the terms and conditions of the Creative Commons Attribution license (http://creativecommons.org/licenses/by/4.0/). 